Mohammed H.ALTaweel and Laith Y.Jabur

University of Kufa, Faculty of Science, Physics Department, Najaf, Iraq Email: laith15musawi@gmail.com

\title{
ASSESSMENT OF NATURAL RADIOACTIVITY AND RADIOLOGICAL HAZARD IN SEDIMENT BOTTOM OF EUPHRATES RIVER
}

\begin{abstract}
:
The level of natural radioactivity has been studied in the bottom river sediments of Euphrates river course through three governorates (AL-Najaf ALAsharf, Babylon and AL- Qadisiya).Where thirty samples from river sediments(ten samples at each governorate) were taken to laboratory for radio analysis. These spectral measurements were carried out by the use of $\mathrm{NaI}(\mathrm{Tl})$ detector that has the dimensions of ( $\left.3^{\prime \prime} \times 3^{\prime \prime}\right)$ high efficiency. The radioactivity of naturally composed radioactivity nuclide, and for natural decay series. The specific activities of the studied samples measured by units $(\mathrm{Bq} \backslash \mathrm{Kg})$ then the spectra of studied samples were analyzed. The specific activities in the three governorates respectively in AL-Najaf AL-Ashraf it has been found the values of ${ }^{40} \mathrm{~K}$ varies from $324.62 \pm 3.15$ to $413.29 \pm 3.8 \mathrm{~Bq} \backslash \mathrm{Kg}$ and average value of $362.46 \pm 4.54 \mathrm{~Bq} \backslash \mathrm{Kg}$. the values of ${ }^{238} U$ from $9.51 \pm 0.53$ to $20.22 \pm 0.8 \mathrm{~Bq} \backslash \mathrm{Kg}$ and average value of $15.28 \pm 9.92 \mathrm{~Bq} \backslash \mathrm{Kg}$. The values of ${ }^{232} \mathrm{Th}$ from $5.3 \pm 0.24$ Social sciences and humanities Mohammed H.ALTaweel and Laith Y.Jabur
\end{abstract}


to $9.92 \pm 0.34 \mathrm{~Bq} \backslash \mathrm{Kg}$ and average value $7.62 \pm 0.26 \mathrm{~Bq} \backslash \mathrm{Kg}$. In Babylon the values of ${ }^{40} \mathrm{~K}$ from $335.49 \pm 3.33$ to $405.26 \pm 3.37 \mathrm{~Bq} \backslash \mathrm{Kg}$ and average value of $381.87 \pm 3.4 \mathrm{~Bq} \backslash \mathrm{Kg}$. the values of ${ }^{238} U$ from $10.02 \pm 0.55$ to $20.00 \pm 0.82 \mathrm{~Bq} \backslash \mathrm{Kg}$ with on average value of $15.24 \pm 0.59 \mathrm{~Bq} \backslash \mathrm{Kg}$. The values of ${ }^{232} \mathrm{Th}$ from $4.9 \pm 0.24$ to $8.45 \pm 0.31 \mathrm{~Bq} \backslash \mathrm{Kg}$ and average value $7.17 \pm 0.19 \mathrm{~Bq} \backslash \mathrm{Kg}$. In ALQadisiya the values of ${ }^{40} K$ from $303.37 \pm 3.21$ to $421.76 \pm 4.06 \mathrm{~Bq} \backslash \mathrm{Kg}$ and average value of $382.88 \pm 9.52 \mathrm{~Bq} \backslash \mathrm{Kg}$. The values of ${ }^{238} U$ from $8.15 \pm 0.54$ to $23.95 \pm 0.95 \mathrm{~Bq} \backslash \mathrm{Kg}$ with on average value of $15.46 \pm 0.74 \mathrm{~Bq} \backslash \mathrm{Kg}$. The values of ${ }^{232} \mathrm{Th}$ from $8.24 \pm 0.34$ to $12.63 \pm 0.39 \mathrm{~Bq} \backslash \mathrm{Kg}$ and average value $9.97 \pm 0.21$ $\mathrm{Bq} \backslash \mathrm{Kg}$.

The resulted average of specific activities in the three governorates were compared to the average values permitted by UNSCEAR for ${ }^{40} \mathrm{~K},{ }^{238} U$ and ${ }^{232} \mathrm{Th}$ which are $(400,32,30) \mathrm{Bq} \backslash \mathrm{Kg}$ respectively, and they were found to be within the permissible values. The average value of Radium Equivalent, activity concentration index, External Hazard index, Internal Hazard index , Absorbed Dose and Excess life time cancer Risk have been calculated. All of them were within permissible limits.

Keyword: Assessment of Radiological, Radiological Hazard, Sediment River, Euphrates River, $\mathrm{NaI}(\mathrm{Tl})$.

\section{Introduction:}


In the early of discoveries of the radioactivity, there was no one of the scientists aware of the risks of this natural radiation. However, later the scientists noticed that several mine workers, exposed to Radon (that is resulted from the dissolution of Uranium isotope or Thorium), were suffering from a killer lung disease, that is recently diagnosed as lung cancer. At that point efforts were devoted to develop a kind of prevention from the radiation exposure for workers in Europe and America between 1913-1916 under the auspices of the national Advisory Committees where they formed international committees like :

- The international Commission on Radiological Protection (ICRP).

- National Council for Radiation Protection and Measurements in the United States (NCRP).

- National Council for Radiation Protection and the Scientific Committee of the United Nations (UNSCEAR) .

- United Nation Scientific Committee on Effects of Atomic Radiation, which was found by twenty countries among the member states members of the united nations. A group of scientists, from these countries, specialized in the fields of radiation physics and biology, annually held meeting to study the Biological effects of the radiation on the living organisms. They study's the effects of radiation both scientifically and statistically. These governmental bodies concern with the publication and application of the instructions and laws that help to protect against radiation dangers[1].

The monitoring process of the environmental radioactivity is of a great importance to ensure the security and safety of the society. So we must know Social sciences and humanities Mohammed H.ALTaweel and Laith Y.Jabur 
the changes in the level of radioactivity because of its harmful effects on the health and genes of human and animals, represented by the natural radiation which is an integral component of our environment and it is similar to the heat and light of the sun. So the emission of low radiation levels of rock or soil, with no contribution of human being with it, is produced from the rocks of the Earth's crust or soil as a result of weathering which means that the rocks disintegrate and analyze [2].

Sediments of Euphrates river can be used as environmental pointer and their ability to detect contamination sources. Detected contaminants are widely recognized radioactivity in the nature consist of three well known radioactive chains of $(\mathrm{U}$, Th and $\mathrm{K})$. The uranium chain formation from ${ }^{238} U$ and ${ }^{235} U$. the environmental dose of the ${ }^{235} U$ is very small [3].

Many singly found radionuclides are also present in nature. The most important is potassium-40, because its ability to emit gamma ray plus beta decay and therefore contributes to gamma-ray radiation exposure [4]. by the use of $\mathrm{NaI}(\mathrm{Tl})$ detector. There are many researchers used $\mathrm{NaI}(\mathrm{Tl})$ technical for different materials such as food, cleaning materials and soil $[5,6,7,8,9]$.

Sediments formation are present in soil and rocks. Radionuclides are present in soil in different amounts, they can easily move in the nature. Radioactivity in sediments is due to the sandy soil, they are derived. The distribution of radioactive nuclei depend on the distribution of soil in the river. The geological and geophysical conditions plays an important factor in distribution of radioactive nuclei in the soil [10]. We know very little about the concentration of radioactive nuclei in the sediments of the bottom Euphrates river. 
The aim of this study is to determine the specific activity of the natural radioactive element $\left({ }^{226} R a,{ }^{232} \mathrm{Th},{ }^{40} \mathrm{~K}\right.$ ) in sediment samples. The samples collected from bottom Euphrates river of Iraq and to figure out the radiological hazard associated with sediments. The sediments are used as one the of the components of building materials.

\section{Samples preparation and measurements :}

A total of (30) sediment samples were collected from the three governorates(AL-Najaf AL-Ashraf , Babylon, AL-Qadisiya) through which Euphrates river passes. Then it moves towards the south of Iraq. Figure(1.a,b,c,d) shows the location of the sampling of the river bottom sediment sampling. Samples were dried and sieved through sieve of certain size of mesh at physics laboratory of department University of Kufa. The samples were weighted and sealed in (Marinelli containers). The sealed containers are contains the samples, were stored for four weeks before doing the measurements. This procedure was applied to allow for radionuclides and its short progeny daughter to decay. Then after the spectral measurements were carried out by the use of $\mathrm{NaI}(\mathrm{Tl})$ detector, that has the size of $\left(3^{\prime \prime} \times 3 "\right)$ was used to carry out the measurements of natural radionuclide content of the sediments of the river bank samples. The resolution of the detector is about $6.4 \%$ at $0.662 \mathrm{Mev} .{ }^{237} \mathrm{Cs}$, which has the ability to distinguish the gamma ray energy, was used for the measuring procedure. The efficiency calibration sources with known energies $\left({ }^{22} \mathrm{Na},{ }^{237} \mathrm{Cs},{ }^{60} \mathrm{Co}\right)$. The net count under photo peak was related to the specific activity radioactive nuclide using the efficiency and energy calibration factors obtained for ${ }^{226} \mathrm{Ra},{ }^{232} \mathrm{Th}$ and ${ }^{40} \mathrm{~K}$ by the following relation [11]. 
$A=\frac{\text { Nnet }}{\varepsilon \cdot I \gamma \cdot m \cdot t}$

Where $(\mathrm{A})$ is the specific activity measured in $(\mathrm{Bq} \backslash \mathrm{kg})$ of the nuclide at beak energy. The net peak counts for a peak energy is $($ Nnet $),(\varepsilon)$ is the detection efficiency at certain energy $(E)$ and $(t)$ is the counting time in seconds for each sample. $(I \gamma)$ is the percentage of gamma-ray emission probability, $(m)$ mass of the measured sample in $(\mathrm{kg})$. Each sample was put on the shielded $\mathrm{Na}(\mathrm{Tl})$ detector for a period of (18000) second. Each count was subtracted from the background. There is a problem in the direct calculation of the activity of ${ }^{238} \mathrm{U}$ and ${ }^{232} \mathrm{Th}$ because of their relatively low gamma-ray intensities, so the activity ${ }^{238} U$ and ${ }^{232} \mathrm{Th}$ can be estimated by calculating the specific activity of ${ }^{214} \mathrm{Bi}$ with gamma-ray line (1764) kev and ${ }^{232} \mathrm{Th}$ by the specific activity of ${ }^{208} \mathrm{Tl}$ with gamma-ray line (2614)kev. The calculation of the activity of ${ }^{40} \mathrm{~K}$ is done directly by calculating gamma-ray line of (1408)kev and that under secular equilibrium. The specific activity of ${ }^{235} U$ was calculated by using the relation[12].

$A_{U-235}=\frac{A_{U-338}}{21.7}$ 


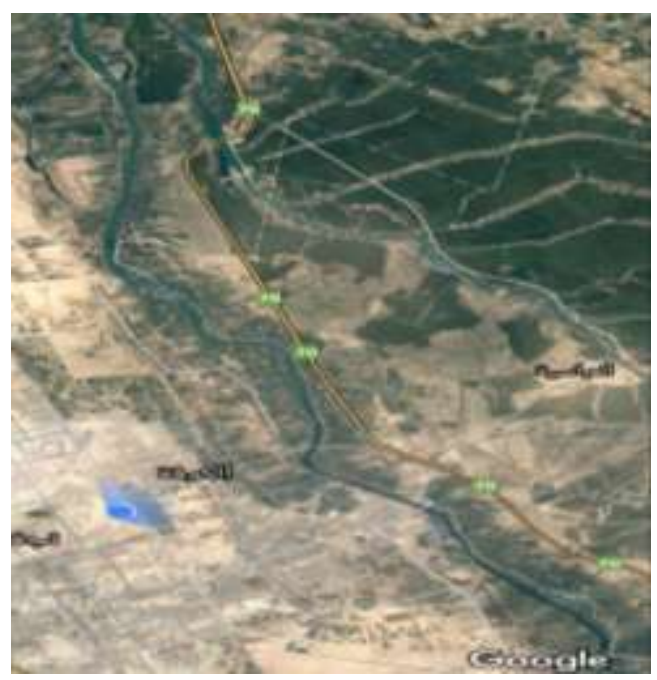

www.journalofresearch.asia info@journalofresearch.asia

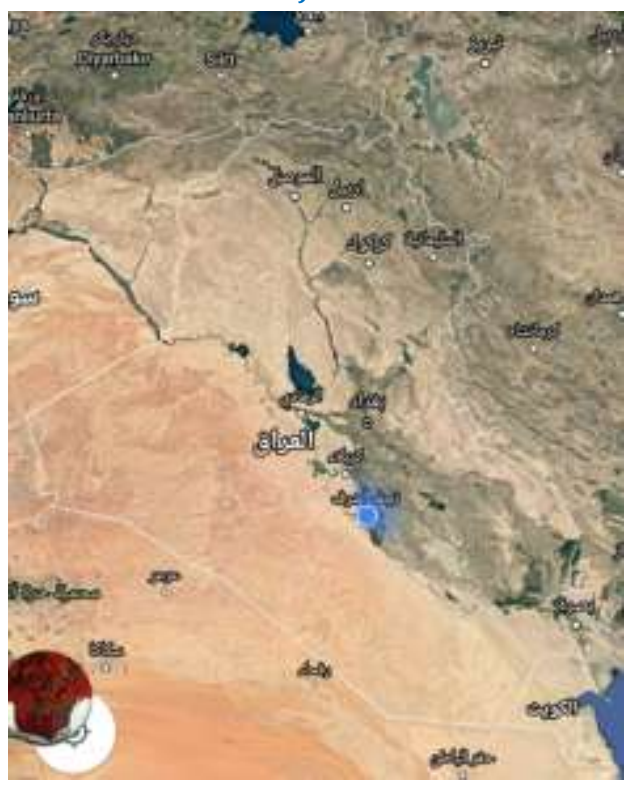

Figure(1.b):Euphrates river in Kufa. Figure(1.a): Euphrates River in Iraq. 

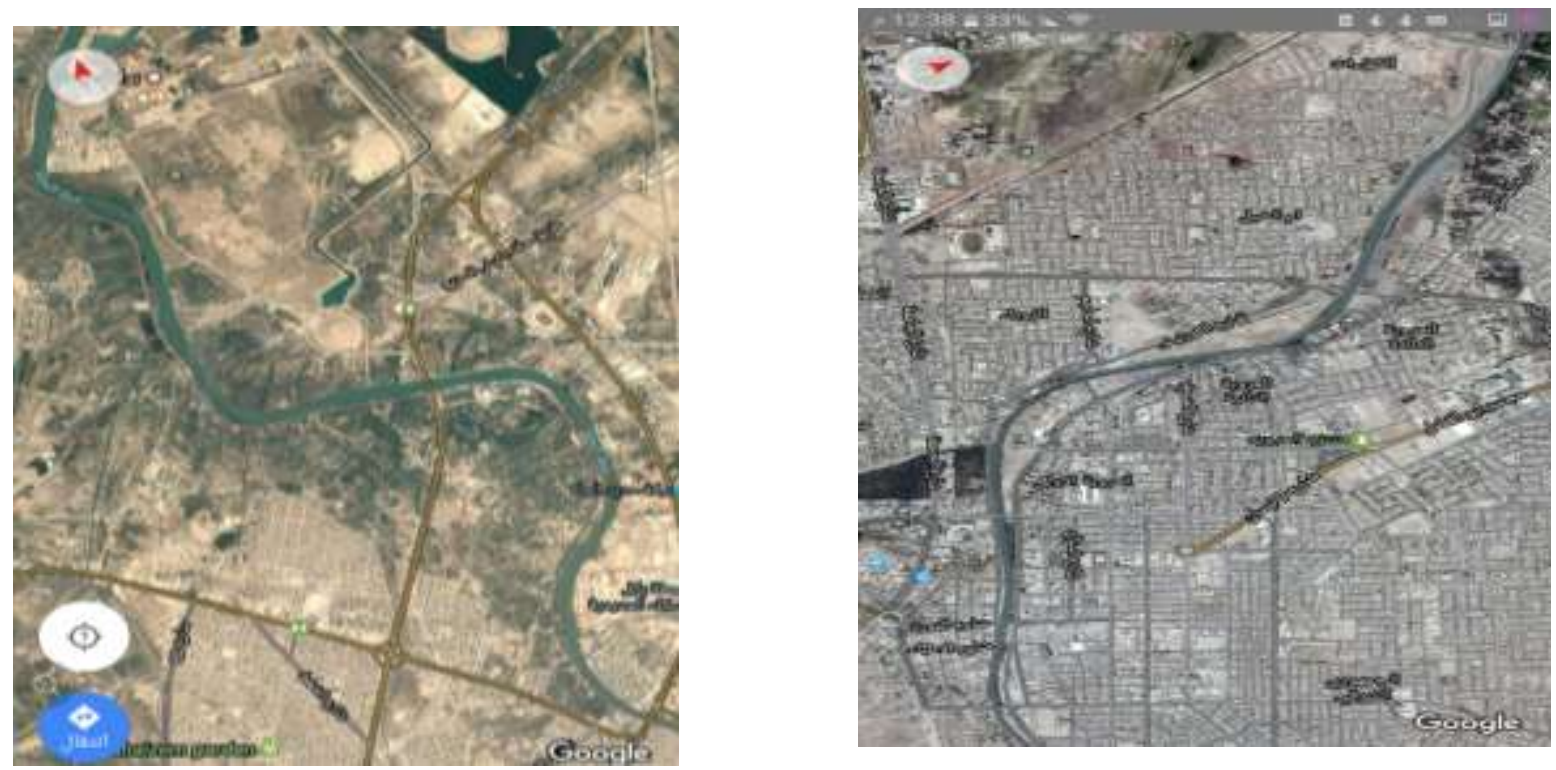

Figure(1.c): Euphrates river in Babylon.

Figure(1.d): Euphrates river in ALQadisiya.

\section{Results and Discussion:}

From table $(1,2,3)$ the mean concentration values of ${ }^{40} \mathrm{~K}$ with standard deviation have been represented. ${ }^{40} \mathrm{~K}$ contributes to the activity of the radioactive elements in river bottom sediment through the three governorates. In ALNajaf AL-Ashraf has the lowest values of ${ }^{40} \mathrm{~K} \quad 324.62 \pm 3.15 \mathrm{~Bq} \backslash \mathrm{kg}$ to highest 
value $413.29 \pm 3.8 \mathrm{~Bq} \backslash \mathrm{kg}$ with in average value of $362 \pm 4.54 \mathrm{~Bq} \backslash \mathrm{kg}$. the values of ${ }^{238} \mathrm{U}$ varies from $8.51 \pm 0.53$ to $20.22 \pm 0.8 \mathrm{~Bq} \backslash \mathrm{kg}$ and the average value 15.28 $\pm 9.92 \mathrm{~Bq} \backslash \mathrm{kg}$. the value of $232 \mathrm{Th}$ varies from $5.3 \pm 0.24$ to $9.92 \pm 0.34 \mathrm{~Bq} \backslash \mathrm{kg}$ with an average value of $7.63 \pm 0.26 \mathrm{~Bq} \backslash \mathrm{kg}$. In Babylon it has been found that the values of ${ }^{40} \mathrm{~K}$ varies from $335.48 \pm 3.33$ to $405.26 \pm 3.73 \mathrm{~Bq} \backslash \mathrm{kg}$ with an the average value of $381.87 \pm 3.4 \mathrm{~Bq} \backslash \mathrm{kg}$. the values of vary ${ }^{238} U$ from $10.02 \pm 0.55$ to $20.00 \pm 0.82 \mathrm{~Bq} \backslash \mathrm{Kg}$ with an average value of $15.24 \pm 0.59 \mathrm{~Bq} \backslash \mathrm{Kg}$. The values of ${ }^{232} \mathrm{Th}$ vary from $4.9 \pm 0.24$ to $8.45 \pm 0.31 \mathrm{~Bq} \backslash \mathrm{Kg}$ and the average value is $7.17 \pm 0.19 \mathrm{~Bq} \backslash \mathrm{Kg}$. In AL-Qadisiya the values of ${ }^{40} \mathrm{~K}$ vary from $303.37 \pm 3.21$ to $421.76 \pm 4.06 \mathrm{~Bq} \backslash \mathrm{Kg}$ and the average value is $382.88 \pm 9.52 \mathrm{~Bq} \backslash \mathrm{Kg}$. the values of ${ }^{238} U$ vary from $8.15 \pm 0.54$ to $23.95 \pm 0.95 \mathrm{~Bq} \backslash \mathrm{Kg}$ with an average value of $15.46 \pm 0.74 \mathrm{~Bq} \backslash \mathrm{Kg}$. The values of ${ }^{232} \mathrm{Th}$ vary from $8.24 \pm 0.34$ to $12.63 \pm 0.39$ $\mathrm{Bq} \backslash \mathrm{Kg}$ and the average value is $9.97 \pm 0.21 \mathrm{~Bq} \backslash \mathrm{Kg}$.

Table (1): Specific Activities of ${ }^{40} \mathrm{~K},{ }^{238} \mathrm{U}$ and ${ }^{232} \mathrm{Th}$ of sediment samples taken for the study in AL Najaf ALAshraf.

\begin{tabular}{|c|c|c|c|c|c|}
\hline \multirow[t]{2}{*}{ No. } & \multirow{2}{*}{$\begin{array}{c}\text { Sample } \\
\text { code }\end{array}$} & \multicolumn{4}{|c|}{ Specific activity in $(\mathrm{Bq} / \mathrm{Kg})$} \\
\hline & & ${ }^{40} K$ & ${ }^{238} U$ & ${ }^{235} U$ & $232 \mathrm{Th}$ \\
\hline 1 & sn1 & $375.83 \pm 3.65$ & $13.74 \pm 0.66$ & 0.63 & $5.64 \pm 0.26$ \\
\hline 2 & sn2 & $392.65 \pm 3.71$ & $15.65 \pm 0.71$ & 0.72 & $7.844 \pm 0.30$ \\
\hline
\end{tabular}




\begin{tabular}{|c|c|c|c|c|c|}
\hline 3 & sn3 & $375.71 \pm 3.66$ & $14.79 \pm 0.69$ & 0.68 & $7.848 \pm 0.30$ \\
\hline 4 & sn4 & $353.64 \pm 3.49$ & $17.53 \pm 0.74$ & 0.80 & $9.22 \pm 0.32$ \\
\hline 5 & sn5 & $363.57 \pm 3.56$ & $20.22 \pm 0.80$ & 0.93 & $9.92 \pm 0.34$ \\
\hline 6 & sn6 & $328.45 \pm 3.29$ & $9.51 \pm 0.53$ & 0.43 & $5.57 \pm 0.25$ \\
\hline 7 & sn7 & $332.13 \pm 3.36$ & $14.53 \pm 0.67$ & 0.66 & $5.30 \pm 0.24$ \\
\hline 8 & $\operatorname{sn} 8$ & $364.77 \pm 3.45$ & $14.52 \pm 0.66$ & 0.66 & $9.02 \pm 0.31$ \\
\hline 9 & $\operatorname{sn} 9$ & $413.29 \pm 3.80$ & $18.87 \pm 0.77$ & 0.86 & $6.55 \pm 0.27$ \\
\hline 10 & sn10 & $324.62 \pm 3.15$ & $13.42 \pm 0.61$ & 0.61 & $6.69 \pm 0.26$ \\
\hline \multicolumn{2}{|c|}{ Average \pm S.D } & $362.46 \pm 4.54$ & $15.28 \pm 0.47$ & 0.70 & $7.36 \pm 0.26$ \\
\hline \multicolumn{2}{|c|}{$\begin{array}{c}\text { World Wide } \\
\text { average }\end{array}$} & 400 & 32 & 10 & 30 \\
\hline
\end{tabular}

Table (2): Specific Activities of ${ }^{40} \mathrm{~K},{ }^{238} \mathrm{U},{ }^{235} \mathrm{U}$ and ${ }^{232} \mathrm{Th}$ of sediment samples taken for the study in Babylon.

\begin{tabular}{|c|c|c|c|c|c|}
\hline \multirow{2}{*}{ No. } & \multirow{3}{*}{$\begin{array}{c}\text { Sample } \\
\text { code }\end{array}$} & ${ }^{40} K$ & ${ }^{238} U$ & ${ }^{235} U$ & ${ }^{232} \mathrm{Th}$ \\
\cline { 3 - 6 } & & & & & \\
\hline 1 & Sb1 & $397.48 \pm 3.69$ & $18.66 \pm 0.76$ & 0.85 & $6.56 \pm 0.28$ \\
\hline 2 & Sb2 & $397.30 \pm 3.8$ & $20.24 \pm 0.82$ & 0.93 & $7.81 \pm 0.31$ \\
\hline 3 & Sb3 & $392.79 \pm 3.83$ & $15.59 \pm 0.73$ & 0.71 & $7.83 \pm 0.32$ \\
\hline 4 & Sb4 & $359.62 \pm 3.54$ & $10.07 \pm 0.56$ & 0.46 & $8.41 \pm 0.32$ \\
\hline 5 & Sb5 & $359.37 \pm 3.54$ & $11.16 \pm 0.59$ & 0.51 & $7.08 \pm 0.29$ \\
\hline 6 & Sb6 & $384.78 \pm 3.59$ & $19.31 \pm 0.77$ & 0.88 & $7.82 \pm 0.3$ \\
\hline 7 & Sb7 & $335.49 \pm 3.33$ & $10.02 \pm 0.55$ & 0.46 & $7.27 \pm 0.29$ \\
\hline 8 & Sb8 & $405.26 \pm 3.73$ & $16.42 \pm 0.72$ & 0.75 & $4.90 \pm 0.24$ \\
\hline
\end{tabular}




\begin{tabular}{|c|c|c|c|c|c|}
\hline 9 & Sb9 & $384.12 \pm 3.62$ & $14.73 \pm 0.68$ & 0.67 & $5.15 \pm 0.24$ \\
\hline 10 & Sb10 & $367.78 \pm 3.52$ & $16.28 \pm 0.71$ & 0.75 & $8.45 \pm 0.31$ \\
\hline Average \pm S.D & $\begin{array}{c}381.88 \pm 3.40 \\
1\end{array}$ & $\begin{array}{c}15.24 \pm 0.59 \\
2\end{array}$ & 0.70 & $7.13 \pm 0.197$ \\
\hline $\begin{array}{c}\text { World Wide } \\
\text { average }\end{array}$ & 400 & 32 & 10 & 30 \\
\hline
\end{tabular}

Table (3): Specific Activities of ${ }^{40} \mathrm{~K}, 238 \mathrm{U}, 235 \mathrm{U}$ and ${ }^{232} \mathrm{Th}$ of sediment samples taken for the study in AL Qadisiya.

\begin{tabular}{|c|c|c|c|c|c|}
\hline \multirow{2}{*}{ No. } & \multirow{2}{*}{$\begin{array}{l}\text { Sample } \\
\text { code }\end{array}$} & \multicolumn{4}{|c|}{ Specific activity in $(\mathrm{Bq} / \mathrm{Kg})$} \\
\hline & & ${ }^{40} K$ & ${ }^{238} U$ & ${ }^{235} U$ & $232 \mathrm{Th}$ \\
\hline 1 & sd1 & $383.1 \pm 3.81$ & $8.87 \pm 0.55$ & 0.40 & $10 \pm 0.35$ \\
\hline 2 & sd2 & $407.5 \pm 3.97$ & $14.61 \pm 0.72$ & 0.67 & $9.49 \pm 0.35$ \\
\hline 3 & sd3 & $303.37 \pm 3.21$ & $16.65 \pm 0.72$ & 0.76 & $10.42 \pm 0.34$ \\
\hline 4 & sd4 & $412.68 \pm 3.97$ & $13.51 \pm 0.68$ & 0.62 & $10.75 \pm 0.37$ \\
\hline 5 & sd5 & $362.29 \pm 3.53$ & $18.89 \pm 0.77$ & 0.87 & $8.32 \pm 0.31$ \\
\hline 6 & sd6 & $390.91 \pm 4.03$ & $23.95 \pm 0.95$ & 1.10 & $8.24 \pm 0.34$ \\
\hline 7 & sd7 & $421.76 \pm 4.06$ & $8.15 \pm 0.54$ & 0.37 & $8.96 \pm 0.34$ \\
\hline 8 & sd8 & $381.68 \pm 3.88$ & $15.29 \pm 0.74$ & 0.70 & $11.34 \pm 0.38$ \\
\hline 9 & sd9 & $374.45 \pm 3.67$ & $19.26 \pm 0.79$ & 0.88 & $9.52 \pm 0.34$ \\
\hline 10 & sd10 & $368.93 \pm 3.63$ & $15.41 \pm 0.71$ & 0.71 & $12.63 \pm 0.39$ \\
\hline & $380.67 \pm 5.27$ & $15.46 \pm 0.74$ & 0.70 & $9.97 \pm 0.21$ \\
\hline
\end{tabular}




\begin{tabular}{|c|c|c|c|c|}
\hline $\begin{array}{c}\text { World Wide } \\
\text { average }\end{array}$ & 400 & 32 & 10 & 30 \\
\hline
\end{tabular}

Figures $(2,3,4)$ : Shows a comparison between the specific activity is a hazard index.

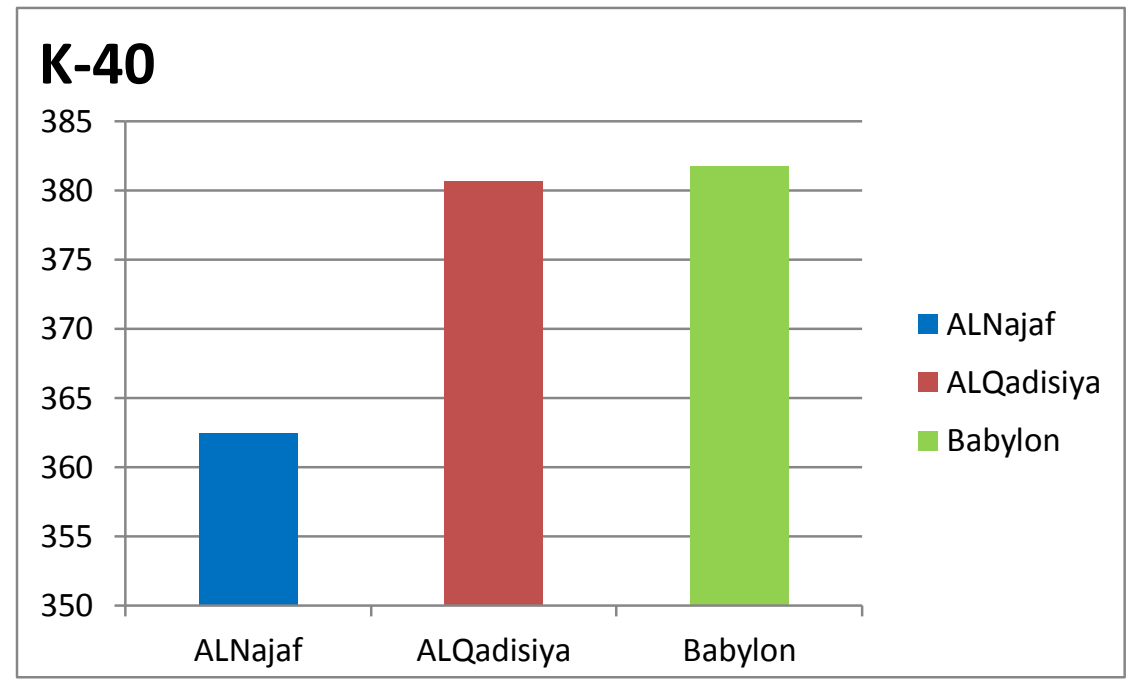

Figure (3): A comparison of K-40 among three governorates. 


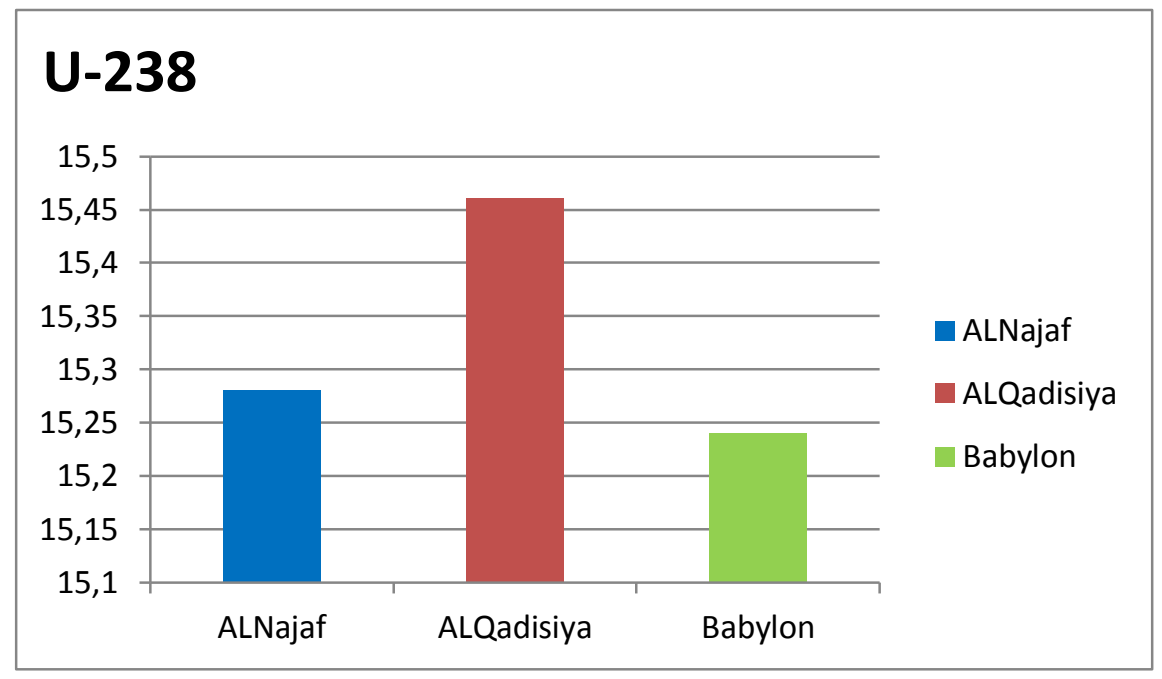

Figure (4): comparison of U-238 among three governorates.

\section{Th-232}

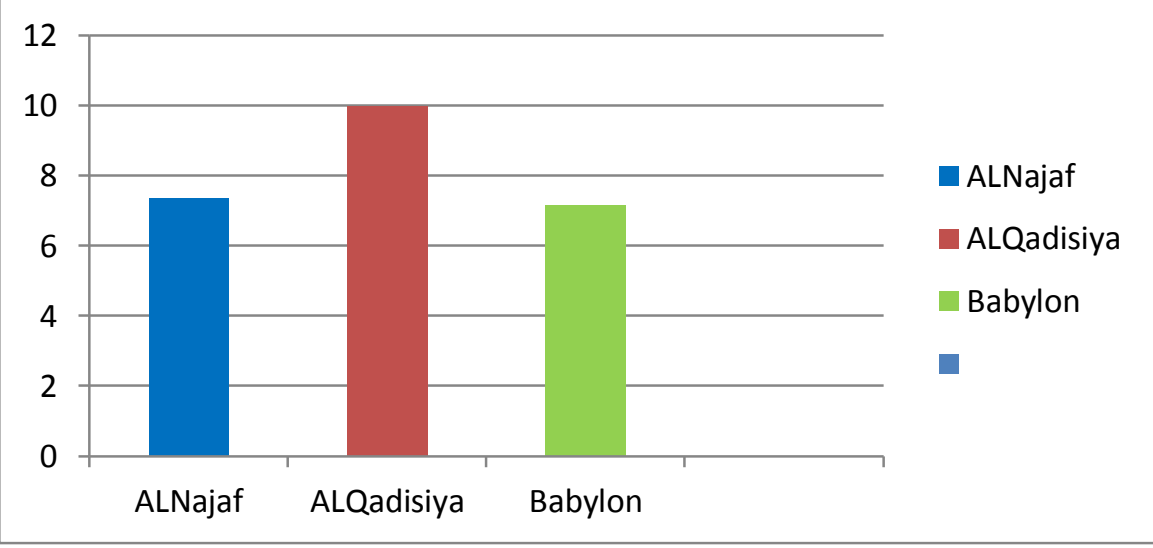


Figure (5): comparison of Th-232 among three governorates.

The Raeq is the estimate of the risk of specific activity measured in units $\mathrm{Bq} \backslash \mathrm{kg}$ , it can be calculated according to the following equation[13,14]:

$R a_{e q}(\mathrm{~Bq} \backslash \mathrm{kg})=A_{U}+1.43 A_{T h}+0.77 A_{K}$

Where $A_{U}, A_{T h}$ and $A_{K}$ are the specific activity of uranium, thorium and potassium respectively. The permissible value of Raeq should be less than (370 $\mathrm{Bq} \backslash \mathrm{kg})[15]$. The activity concentration index can be calculated from the following equation[16,17]:

$I \gamma=\frac{A_{U}}{150}+\frac{A_{T h}}{100}+\frac{A_{K}}{1500}$

The internal hazard $\left(H_{i n}\right)$ is calculated using the following relation[18]:

$H_{\text {in }}=\frac{A_{U}}{185}+\frac{A_{T h}}{259}+\frac{A_{K}}{4810}$

The external hazard index $\left(H_{e x}\right)$ can be calculated using the following equation[19,20]:

$H_{e x}=\frac{A_{U}}{730}+\frac{A_{T h}}{259}+\frac{A_{K}}{4610}$

Where the absorbed dose rate in air $\left(A_{D}\right)$ can be calculated by using the relation[15]: 
$A_{D}(\mathrm{nGy} \backslash \mathrm{hr})=0.462 A_{U}+0.621 A_{T h}+0.04 A_{K}$

The results are showed in tables $(4,5,6)$ for the three governorates(AL-Najaf ALAshraf, Babylon, ALQadisiya).

Table (4): Results of Raeq ,AD ,Hex ,Hin , I $\gamma$ of ALNajaf ALAshraf.

\begin{tabular}{|c|c|c|c|c|c|c|}
\hline No. & $\begin{array}{c}\text { Sample } \\
\text { code }\end{array}$ & $\begin{array}{c}\text { Raeq } \\
(B q / k g)\end{array}$ & $\begin{array}{c}A D \\
(n G y / h)\end{array}$ & Hin & Hex & $I \gamma$ \\
\hline 1 & sn1 & 50.76 & 25.44 & 0.174 & 0.137 & 0.199 \\
\hline 2 & sn2 & 57.11 & 28.34 & 0.197 & 0.154 & 0.222 \\
\hline 3 & sn3 & 54.95 & 27.24 & 0.188 & 0.148 & 0.214 \\
\hline 4 & sn4 & 57.96 & 28.42 & 0.204 & 0.156 & 0.222 \\
\hline 5 & sn5 & 62.41 & 30.5 & 0.223 & 0.168 & 0.238 \\
\hline 6 & sn6 & 42.78 & 21.46 & 0.141 & 0.115 & 0.169 \\
\hline 7 & sn7 & 47.69 & 23.77 & 0.168 & 0.128 & 0.186 \\
\hline 8 & sn8 & 55.52 & 27.37 & 0.189 & 0.149 & 0.215 \\
\hline 9 & sn9 & 60.08 & 29.92 & 0.213 & 0.162 & 0.233 \\
\hline 10 & sn10 & 47.99 & 23.78 & 0.166 & 0.129 & 0.186 \\
\hline \multicolumn{2}{|c|}{$\begin{array}{c}\text { Average } \pm \\
\text { S.D }\end{array}$} & $53.73 \pm 0.98$ & $\begin{array}{c}26.62 \pm 0.4 \\
6\end{array}$ & $\begin{array}{c}0.186 \pm 0.00 \\
3\end{array}$ & $\begin{array}{c}0.145 \pm 0.00 \\
2\end{array}$ & $\begin{array}{c}0.209 \pm 0.00 \\
3\end{array}$ \\
\hline \multicolumn{2}{|c|}{$\begin{array}{c}\text { World Wide } \\
\text { average }\end{array}$} & $<370$ & $<55$ & $<1$ & $<1$ & $<1$ \\
\hline
\end{tabular}


Table (5): Results of Raeq , AD ,Hex , Hin , I $\gamma$ of Babylon.

\begin{tabular}{|c|c|c|c|c|c|c|}
\hline No. & $\begin{array}{c}\text { Sampl } \\
\text { e code }\end{array}$ & $\begin{array}{c}\text { Raeq } \\
(B q / k g)\end{array}$ & $\begin{array}{c}A D \\
(n G y / h)\end{array}$ & Hin & Hex & I \\
\hline 1 & Sb1 & 58.660 & 29.163 & 0.208 & 0.158 & 0.227 \\
\hline 2 & Sb2 & 61.999 & 30.635 & 0.222 & 0.167 & 0.238 \\
\hline 3 & Sb3 & 57.031 & 28.311 & 0.196 & 0.154 & 0.222 \\
\hline 4 & Sb4 & 52.473 & 26.182 & 0.168 & 0.141 & 0.207 \\
\hline 5 & Sb5 & 48.967 & 24.423 & 0.162 & 0.132 & 0.192 \\
\hline 6 & Sb6 & 60.121 & 29.690 & 0.214 & 0.162 & 0.231 \\
\hline 7 & Sb7 & 46.255 & 23.013 & 0.152 & 0.124 & 0.181 \\
\hline 8 & Sb8 & 54.631 & 27.444 & 0.191 & 0.147 & 0.214 \\
\hline 9 & Sb9 & 51.684 & 25.939 & 0.179 & 0.139 & 0.202 \\
\hline 10 & Sb10 & 56.687 & 27.963 & 0.197 & 0.153 & 0.219 \\
\hline Average \pm & $54.851 \pm 0.7$ & $27.276 \pm 0.3$ & $0.189 \pm 0.00$ & $0.148 \pm 0.00$ & $0.213 \pm 0.00$ \\
\hline \multicolumn{2}{|c|}{ S.D } & 90 & 77 & 3 & 2 & 2 \\
\hline \multicolumn{2}{|r|}{ World Wide } & $<370$ & $<55$ & $<1$ & $<1$ & $<1$ \\
\hline \multicolumn{2}{|r|}{ average } & & & & & $<$ \\
\hline
\end{tabular}

Table (6): Results of Raeq , AD , Hex , Hin , I $\gamma$ of AL Qadisiya. 

info@journalofresearch.asia

\begin{tabular}{|c|c|c|c|c|c|c|}
\hline No. & $\begin{array}{l}\text { Sampl } \\
\text { e code }\end{array}$ & $\begin{array}{c}\text { Raeq } \\
(\mathrm{Bq} / \mathbf{k g})\end{array}$ & $\begin{array}{c}A D \\
(n G y / h)\end{array}$ & Hin & Hex & $\mathrm{I}_{\gamma}$ \\
\hline 1 & Sd1 & 52.686 & 26.120 & 0.166 & 0.142 & 0.207 \\
\hline 2 & $\mathrm{Sd} 2$ & 59.566 & 29.478 & 0.200 & 0.160 & 0.232 \\
\hline 3 & Sd3 & 54.916 & 26.639 & 0.193 & 0.148 & 0.208 \\
\hline 4 & Sd4 & 60.671 & 29.948 & 0.200 & 0.163 & 0.236 \\
\hline 5 & Sd5 & 58.702 & 28.867 & 0.209 & 0.158 & 0.225 \\
\hline 6 & Sd6 & 65.846 & 32.348 & 0.242 & 0.177 & 0.251 \\
\hline 7 & Sd7 & 53.453 & 26.771 & 0.166 & 0.144 & 0.212 \\
\hline 8 & Sd8 & 60.907 & 29.834 & 0.205 & 0.164 & 0.234 \\
\hline 9 & Sd9 & 61.721 & 30.269 & 0.218 & 0.166 & 0.236 \\
\hline 10 & Sd10 & 61.896 & 30.140 & 0.208 & 0.167 & 0.237 \\
\hline \multicolumn{2}{|c|}{$\begin{array}{c}\text { Average } \pm \\
\text { S.D }\end{array}$} & $\begin{array}{c}59.036 \pm 0.6 \\
5\end{array}$ & $\begin{array}{c}29.042 \pm 0.3 \\
1\end{array}$ & $\begin{array}{c}0.201 \pm 0.00 \\
3\end{array}$ & $\begin{array}{c}0.159 \pm 0.00 \\
1\end{array}$ & $\begin{array}{c}0.228 \pm 0.00 \\
2\end{array}$ \\
\hline \multicolumn{2}{|c|}{$\begin{array}{c}\text { World Wide } \\
\text { average }\end{array}$} & $<370$ & $<55$ & $<1$ & $<1$ & $<1$ \\
\hline
\end{tabular}


We can notice that the average value of Raeq in the three governorates(ALNajaf AL-Asharf , Babylon and AL- Qadisiya) respectively(53.73 \pm 0.98$)$, $(54.85 \pm 0.79)$ and $(59.036 \pm 0.65) \mathrm{Bq} \backslash \mathrm{kg}$, so we can say that we are in the safe side since the permissible average worldwide value is less than (370) Bq $\backslash \mathrm{kg}$. The $\left(A_{D}\right)$ average values are $(26.62 \pm 0.46),(27.276 \pm 0.337),(29.042 \pm 0.31)$ in units of (nGy $\backslash$ hr) for the three governorates respectively. The permissible value is $(<55) \mathrm{nGy} \backslash$ hr.

The (Hin) average values for the three governorates are respectively $(0.186 \pm 0.003),(0.189 \pm 0.003)$ and $(0.201 \pm 0.003)$. the worldwide average value is less than(1). The (Hex) average value in the three governorates are given respectively as $(0.145 \pm 0.002),(0.148 \pm 0.002)$ and $(0.159 \pm 0.001)$. the worldwide average value $(<1)$.

The tables $(7,8,9)$ describe the (AEDE) in (mSv $\backslash \mathrm{hr}),\left(A E D E_{\text {outdoor }}\right)$ in (mSv $\backslash \mathrm{hr}$ ) , $\left(A E D E_{I N \text { door }}\right)$ in $(\mathrm{mSv} \backslash \mathrm{hr})$, and ELCR $\times 10^{-3}$ in the three governorates (ALNajaf AL-Ashraf, Babylon, ALQadisiya) in respective.

Table (7) : Results of (AEDE)indor , (AEDE)outdoor , AEDE and ELCR in ALNajaf.

\begin{tabular}{|c|c|c|c|c|c|}
\hline No. & $\begin{array}{c}\text { Sampl } \\
\text { e code }\end{array}$ & $\begin{array}{c}(A E D E) \text { indo } \\
(m S v / y)\end{array}$ & $\begin{array}{c}\text { (AEDE)outdoc } \\
(m S v / y)\end{array}$ & $\begin{array}{c}A E D E \\
(m S v / y)\end{array}$ & $\begin{array}{c}\text { ELCR } \\
\times 10^{-3}\end{array}$ \\
\hline 1 & sn1 & 0.125 & 0.031 & 0.16 & 0.56 \\
\hline 2 & sn2 & 0.139 & 0.035 & 0.17 & 0.595 \\
\hline 3 & sn3 & 0.134 & 0.033 & 0.17 & 0.595 \\
\hline 4 & sn4 & 0.14 & 0.035 & 0.17 & 0.595 \\
\hline
\end{tabular}




\begin{tabular}{|c|c|c|c|c|c|}
\hline 5 & sn5 & 0.15 & 0.037 & 0.19 & 0.665 \\
\hline 6 & sn6 & 0.105 & 0.026 & 0.13 & 0.455 \\
\hline 7 & sn7 & 0.117 & 0.029 & 0.15 & 0.525 \\
\hline 8 & sn8 & 0.134 & 0.034 & 0.17 & 0.595 \\
\hline 9 & sn9 & 0.147 & 0.037 & 0.18 & 0.63 \\
\hline 10 & sn10 & 0.117 & 0.029 & 0.15 & 0.525 \\
\hline $\begin{array}{c}\text { Average } \pm \\
\text { S.D }\end{array}$ & $0.131 \pm 0.002$ & $0.033 \pm 0.0005$ & $0.16 \pm 0.002$ & $0.574 \pm 0.009$ \\
\hline $\begin{array}{c}\text { World Wide } \\
\text { average }\end{array}$ & 0.42 & 0.08 & 0.50 & $\ldots \ldots \ldots . .$. \\
\hline
\end{tabular}

Table (8) :Results of (AEDE)indor , (AEDE)outdoor , AEDE and ELCR in Babylon.

\begin{tabular}{|c|c|c|c|c|c|}
\hline No. & $\begin{array}{c}\text { Sample } \\
\text { code }\end{array}$ & $\begin{array}{c}(A E D E) \text { indo } \\
(m S v / y)\end{array}$ & $\begin{array}{c}(\text { AEDE }) \text { outdo } \\
(m S v / y)\end{array}$ & $\begin{array}{c}A E D E \\
(m S v / y)\end{array}$ & $\begin{array}{c}\text { ELCR } \\
\times 10^{-3}\end{array}$ \\
\hline 1 & sb1 & 0.143 & 0.035 & 0.178 & 0.623 \\
\hline 2 & sb2 & 0.150 & 0.037 & 0.187 & 0.654 \\
\hline
\end{tabular}




\begin{tabular}{|c|c|c|c|c|c|}
\hline 3 & sb3 & 0.138 & 0.034 & 0.173 & 0.605 \\
\hline 4 & sb4 & 0.128 & 0.032 & 0.160 & 0.56 \\
\hline 5 & sb5 & 0.119 & 0.029 & 0.149 & 0.521 \\
\hline 6 & ab6 & 0.145 & 0.036 & 0.182 & 0.637 \\
\hline 7 & sb7 & 0.112 & 0.028 & 0.141 & 0.493 \\
\hline 8 & sb8 & 0.134 & 0.033 & 0.168 & 0.588 \\
\hline 9 & sb9 & 0.127 & 0.031 & 0.159 & 0.556 \\
\hline 10 & sb10 & 0.137 & 0.034 & 0.171 & 0.598 \\
\hline Average \pm S.D & $0.133 \pm 0.001$ & $0.033 \pm 0.0003$ & $0.167 \pm 0.002$ & $0.583 \pm 0.008$ \\
\hline \multicolumn{2}{|c|}{ World Wide } & 0.42 & 0.08 & 0.50 & $\ldots . . . . . .$. \\
\hline \multicolumn{2}{|c|}{ average } & & & & \\
\hline
\end{tabular}

Table (9) :Results of (AEDE)indor , (AEDE)outdoor, AEDE and ELCR in ALQadisiya.

\begin{tabular}{|c|c|c|c|c|c|}
\hline \multirow{2}{*}{ No. } & \multirow{2}{*}{$\begin{array}{c}\text { Sample } \\
\text { code }\end{array}$} & \multicolumn{2}{|c|}{$(A E D E)$ indo $(A E D E)$ outdod } & \multirow{2}{*}{$\begin{array}{c}A E D E \\
(m S v / y)\end{array}$} & \multirow{2}{*}{$\begin{array}{l}\text { ELCR } \\
\times 10^{-3}\end{array}$} \\
\hline & & $(m S v / y)$ & $(\boldsymbol{m S} \boldsymbol{v} / \boldsymbol{y})$ & & \\
\hline 1 & Sd1 & 0.128226 & 0.032056 & 0.160282 & 0.560989 \\
\hline 2 & Sd2 & 0.144708 & 0.036177 & 0.180885 & 0.633098 \\
\hline 3 & Sd3 & 0.130771 & 0.032693 & 0.163464 & 0.572124 \\
\hline 4 & Sd4 & 0.147018 & 0.036754 & 0.183772 & 0.643202 \\
\hline 5 & Sd5 & 0.141712 & 0.035428 & 0.177139 & 0.619988 \\
\hline 6 & Sd6 & 0.158798 & 0.0397 & 0.198498 & 0.694741 \\
\hline 7 & Sd7 & 0.131419 & 0.032855 & 0.164273 & 0.574956 \\
\hline 8 & Sd8 & 0.146458 & 0.036615 & 0.183073 & 0.640754 \\
\hline
\end{tabular}




\begin{tabular}{|c|c|c|c|c|c|}
\hline 9 & Sd9 & 0.148592 & 0.037148 & 0.185741 & 0.650092 \\
\hline 10 & Sd10 & 0.147958 & 0.03699 & 0.184948 & 0.647318 \\
\hline \multicolumn{2}{|c|}{ Average \pm S.D } & $0.142 \pm 0.001$ & $0.035 \pm 0.0003$ & $0.178 \pm 0.001$ & $0.623 \pm 0.006$ \\
\hline \multicolumn{2}{|c|}{$\begin{array}{c}\text { World Wide } \\
\text { average }\end{array}$} & 0.42 & 0.08 & 0.50 & $\ldots . . . . . .$. \\
\hline
\end{tabular}

The $\left(A E D E_{\text {indoor }}\right) \mathrm{mSv} \backslash \mathrm{hr}$ are $(0.131 \pm 0.002),(0.133 \pm 0.001),(0.142 \pm 0.001)$ for the three governorates respectively where the worldwide average value is $(0.42) \mathrm{mSv} \backslash \mathrm{hr}$, so it is less than the permissible value. Also ( $\left.A E D E_{\text {outdoor }}\right)$ in $\mathrm{mSv} \backslash \mathrm{hr}$ are $(0.033 \pm 0.0005),(0.033 \pm 0.0003),(0.035 \pm 0.003)$ for three governorates respectively, which is below the permissible worldwide average value is (0.08) $\mathrm{mSv} \backslash \mathrm{hr}$. The (AEDE) in $\mathrm{mSv} \backslash \mathrm{yr}$ for the three governorates respectively $(0.16 \pm 0.002),(0.167 \pm 0.002),(0.178 \pm 0.001)$ all the values are below the permissible worldwide average value which is $(0.5) \mathrm{mSv} \backslash \mathrm{yr}$. the last factor we concern about it is $\left(\mathrm{ELCR} \times 10^{-3}\right)$, the values are $(0.574 \pm 0.009)$, $(0.583 \pm 0.008),(0.623 \pm 0.006)$ in three governorates respectively. From the above values we conclude that the sediment of river is safe for using as building material. The deference between the specific activities for ${ }^{40} \mathrm{~K}$ for the three governorates is higher in Babylon governorate than AL-Qadisiya and ALNajaf AL-Ashraf governorates.

Also ${ }^{238} \mathrm{U}$, ${ }^{232} \mathrm{Th}$ specific activity in AL-Qadisiya governorate is higher than Babylon and AL-Najaf AL-Ashraf governorates. This difference is due to the Social sciences and humanities Mohammed H.ALTaweel and Laith Y.Jabur 
geological nature of the soil. We have found that the risk of cancer factor is very little in the three governorates under study.

\section{Recommendations}

1- It is recommended to measure the radioactivity of river sediments before it is used for agricultural purposes.

2- It is also recommended to avoid draining of sewerage water directly into river. It is also recommended to establishing sewerage water refineries.

3- It is also advisable to avoid collecting the waste products of the factories, that lay near the river, into the stream course of the river. 


\section{Reference:}

[1] Vena C., “Advanced Nuclear Physics", $1^{\text {st }}$ Edition , Global Media, (2009).

[2] Ngachin M, Garavaglia M, Giovani C, Njock MG, Nourreddine A. Radioactivity level and soil radon measurement of a volcanic area in Cameroon. Journal of Environmental Radioactivity. 99: 1056-1060,( 2008).

[3] Walley EL-dine,N. , A.EL-Shershabey , F.Ahmed and A.S.Abdel-Haleem. Measurement of Radioactivity and Radon Exhalation Relate in Different kinds of Marbles and Granite. Appl. Radiation isotopes 55:853-860.(2001) .

[4] Xineei, 1, w.Lingqing, J.Xiaoddon, Y,Leipeng and D. Gelian. Specific Activity and Hazards of Archeozic- Cambrian Rock Samples collected from the Weidei area of Shanxi, China. Radiate. Prot. Dosimeter. 118:352-359,(2006).

[5] Ali Abid Abojassim, Lubna A. Al-Alasadi, Ahmed R. Shitake, Faeq A. ALTememie and Afnan A. Husain, " Assessment of Annual Effective Dose for Natural Radioactivity of Gamma Emitters in Biscuit Samples in Iraq", Journal of Food Protection, Vol. 78, No. 9, P. 1766-1769, (2015).

[6] Ali Abid Abojassim, "Study of Norm and Some Radiological Parameters in Instant Noodles Sold in Iraq", World Applied Sciences Journal Vol. 33, No.6, P. 974-979, (2015).

[7] Ali Abid Abojassim, D. M. Dahir, A. S. Alaboodi and A. H. Abonasria," Annual Effective Dose of Gamma Emitters in Adults and Children for Some Types of Rice Consumed in Iraq", Journal of Food Protection, Vol. 79, No. 12, Pages 2174-2178,(2016).

[8] Ali Abid Abojassim, Husain Hamad Al-Gazaly, Eman Sabah Obied, Natural Radioactive Contamination in Shampoo and Dishwashing Samples Social sciences and humanities Mohammed H.ALTaweel and Laith Y.Jabur 
Used in Iraq By NaI(Tl) detector, Asian journal of chemistry, Vol.28, No.10, P.2173-2176, (2016).

[9] Ali Abid Abojassim1, Mohanad H. Oleiwi, Mohammad Hassan, " Natural Radioactivity and Radiological Effects in Soil Samples of the Main Electrical Stations at Babylon Governorate", nuclear physics and atomic energy , Vol. 17 No. 3,(2016).

[10] Florou, H. and P.Kritidis. "Gamma Radiation Masurmentents and Does Rate in the Coastel Area of a Volcanic Islend. Aegean Sea, Greece". Radiat. Prot. Dosimeter. 45:277-279(1992) .

[11] Beretka J. and P.MathewP.J. "Natural Radioactivity building Materials, industrial wastes and by-products". Jounal of health physics, vol.4 No 8pp8795(1985).

[12] Mukhammedov S. and Kutbedinov A. "K-40 RADIOACTIVITY OF Seismactive Zone in Uzbkistan". Journal of Nudear and Radiation Physics. Vol.1.Vo.1 pp.11-16. (2006).

[13] Mirjana B., Saeed M., Velbor B. and Scepan S. "Radioactivity of send from several renowned public beaches and assessment of corresponding environment risks. "Journal of the Serbain Chemical Society, Vol. 74, No. 4, pp 461-470.(2009).

[14] Papadopoulos A. , Christofides G., Koroneos A., Papadopoulou L., Papstefanou C. and Stoulos S., "Natural Radiation index of the major plutomic bodies in Greece". Journal of Environmental Radioactivity" Vol.124,pp:227-238, (2013) . 
[15] Jose A.Jorge J., Cleomaci M., Sueldo V. and Romilton D., "Analysis of K40 levels in soil using gamma spectrometry Brazilian archives of biology and technology". Vol. 48 , pp.221-228, (2005).

[16] Hermen C., Thomas E.J., "Health physics", 4 ${ }^{\text {th }}$ Edition, Mc Grow-Hill companies, Inc.,(2009).

[17] H.M.Schloat .Stone Production Tarrytown, " Radiation detector" prenticeHALL Media-University Saints Malaysia Library.(1972).

[18] Spatium, "Cosmic Rays", published by Association proissi, Institute, No11. (2003).

[19] Brigido F.O., Montalvan E.A., Rosa S.R., Tomas Z.J.and Hernandez P.A., "Natural Radionuclide content in Building materials and gamma dose rate in Environmental Radioactivity", Vol.99,pp,834-837,(2008).

[20] Gordon G, Practical Gamma-ray Spectrometry, $2^{\text {nd }}$, Edition, John W, and Son , Ltd, SBN,316,(2008). 